\title{
A Critique of Atheistic Humanism in the Quest for Human Dignity
}

\author{
Precious Uwaezuoke Obioha \\ Department of Philosophy, Faculty of Arts, Olabisi Onabanjo University, \\ Ago-Iwoye, Nigeria \\ Email: unclepees@yahoo.com
}

Received September 26 ${ }^{\text {th }}$, 2012; revised October 27 ${ }^{\text {th }}$, 2012; accepted November $10^{\text {th }}$, 2012

\begin{abstract}
A challenge confronting the human person in contemporary society is the abuse to his personality which constitutes a bane to his dignity and well-being which has continued to be on the increase despite various theoretical attempts at addressing the issue of abuse to human dignity. One of such theoretical attempts, which is atheistic humanism, has failed in its quest to enhancing the dignity of man because it has neglected the theistic background necessary for understanding, relating to and the treatment of the human person. This paper therefore, aims at a critical analysis of atheistic humanism in its quest for human dignity with a view to showing its implications for the dignity and well-being of man. The paper employs the critical method of philosophy with a view to showing the inconsistencies and the implications of an atheistic humanistic understanding of man. The paper thereafter states that a theistic humanistic understanding and treatment of the human person better provides the ground for the pursuit and realization of human dignity and well-being.
\end{abstract}

Keywords: Humanism; Human Dignity; Human Well-Being; Theism; Human Values; Human Person

\section{Introduction}

A major problem in the contemporary society is the rate at which human life is being pulverized and human dignity degraded with reckless abandon, which is due largely to a wrong or inadequate understanding of the human person. Human life is increasingly becoming capricious and constantly under threat of imminent extinction. There is much frustration in the world today, coupled with wars and counter wars, unending civil unrests and terrorist attacks in almost all the continents of the world. On daily bases, there are undeniable cases of abuse of the fundamental human rights of the people and constant violations of the dignity of man.

However, as characteristic of man-the Homo sapiens, he is constantly in search for the truth for a better life. So he evolves ideas and theories that he thinks will help liberate him and restores to him his dignity and honour for a flowering personality. One of such theories which he claims can restore human dignity and promote human well-being is Atheistic Humanism. Atheistic humanism emphasizes the dignity and worth of the individual and appears to be in the crusade for the pursuit of the dignity of the human person. Although the pursuit of human dignity and worth is the goal of atheistic humanism, however in this paper I argue that this goal as set out by atheistic humanism cannot be achieved and is not achievable given the philosophy behind atheistic humanism. This philosophy is counter-productive to the achievement of human well-being. Through many other arguments which I canvassed for in this paper, I come to agree with Maduabuchi Dukor that humanism that is not theistically founded and coloured cannot promote human values and consequently cannot promote human dignity.

There are two major approaches or better still two kinds of humanism. One, those who give humanism a secular or atheis- tic approach and two, those who give it a theistic approach. However, the name humanism is popularly understood from its secular/atheistic perspective. In this paper, the term humanism would be taken to refer to secular/atheistic humanism unless where otherwise stated.

Dignity is a word for "worth", and a theory of dignity is a philosophy of value. In the Thomistic synthesis, dignity or value is imbedded in substance, an objective reality distinct from, though related to, any subjective reaction to it. The honour due dignity does not lie in the object, but it is a reaction to some excellence in that object of honour (Aquinas 1-II, q 2). So, dignity is the intrinsic worth that inheres in every human being. From the Catholic perspective, the source of human dignity is rooted in the concept Imago Dei, and our ultimate destiny of union with God.

\section{What Is Humanism?}

The question what is humanism is pertinent here because the answer to it will enable us to see whether the logic of humanism is sound enough to take us to its acclaimed goal of ensuring human total well-being and dignity. According to Paul Kurtz (2000) who is regarded today as the father of secular humanism, humanism is a Eupraxophy. For him Eupraxophy is derived from the following roots: eu-praxis, and Sophia. Eu-is a prefix that means "good," "well”, "advantageous." Praxis (or prassein) refers to "action doing, or practice." (Eupraxia means "right action" or "good conduct". The suffix Sophia is derived from sophos ("wise") and means "wisdom". Humanism as a eupraxophy is a philosophy of good and wise action. In humanism the action is not only good and wise but also philosophical, scientific and ethical in out-look (Kurtz, 2000). According to Micola Abbagnano (1967) humanism locates the source 
of values on human rationality and therefore opposed to all varieties of beliefs that seek supernatural sanction for their values. Dukor writes that, "one of the earliest philosophers, and one of the most important to atheistic humanist thinking, is Protagoras who founded the school of professional travelling teachers known as "Sophists" on the principle that practical human knowledge is more useful than searching for the whole truth. This humanism has man as its centre point. It originated from man and ends in man. The referent point is not God, the creator but the material” (Dukor, 2010: p. 64).

It is in this light that many trace humanism to the ancient Greek philosopher Protagoras, who said, "Man is the measure of all things". The interpretation today is that man is the ultimate standard by which all life is measured and judged. Thus values, law, justice, good, beauty, and right and wrong all are to be judged by man made rules with no credence to either God or the Bible. Largely corroborating this view, Angeles (1981: p. 116) defines philosophical humanism as follows:

A philosophy that 1 ) regards the rational individual as the highest values; 2) considers the individual to be the ultimate source of value; and 3) is dedicated to fostering the individual's creative and moral development in meaningful and rational way without reference to concepts of the supernatural.

So said, it appears that all atheistic humanists believe that moral values are relative to human experience; that all intrinsic moral values are based on human desires and interest; that humans rather than some divine being decide what is morally valuable. These are various interpretations of the thesis that humans are the measure of all things. The roots of modern secular humanism date back to the renewed emphasis on man during the renaissance. This revival of classical leaning and emphasis on man did not exclude God as man's maker, but it focused attention away from Him, as man made great stride on his own. Later God was de-emphasized to the point where he was no longer seen as an infinite worker in creation and father to mankind and before long, deism became a prominent view. Deism affirmed belief in God, but a God who was not involved in the affairs of men. Deism soon gave way to naturalism, a world view which dismissed God completely from the scene. Humanism entered the nineteenth century through the French philosopher, Comte, who was committed to the secularization of science, and through British utilitarianism via English deism. These serve as a backdrop for twentieth century naturalism and pragmatism. Through such men as Schiller and especially Dewey, the modern tenets of secular humanism began to take their expressed form.

What constitutes the principles, the ideals, and the goals of secular humanism can be found in the Humanism Manifesto I and II. These documents spell out the vision and the mission of humanism. In 1933 a group of thirty-four liberal humanists in the United State defined and enunciated the philosophical and religious principles that seemed to them fundamental. They drafted Humanist Manifesto I which was concerned with expressing a general philosophical and religious outlook that rejected orthodox and dogmatic positions and provided meaning and direction, unity and purpose to human life. It was also committed to reason, science, and democracy (Kurtz, 1973). The Humanist Manifesto I reflected the general optimism of the time immediately after World War I. Mankind was convinced that it had ably weathered, in the war, the greatest evil imaginable, and that the future perfection of humanity was now possible. Mankind had proved that it could triumph over evil.

In summary, the Humanist Manifesto I dealt with 15 major themes, or convictions, of secular humanism. It asserted that the universe was self-existing and not created; that man is a result of a continuous natural process; that mind is a projection of body and nothing more; that man is molded mostly by his creature; that there is no supernatural; that man has outgrown religion and any idea of God; that man's goal is the development of his own personality, which ceases to exist at death; that man will continue to develop to the point where he will look within himself and to the natural world for the solution to all his problems; that all institutions and or religions that in some way impede this "human well-being" must be changed; that socialism is the ideal form of economics and that all of mankind deserves to share in the fruits from following the above tenets.

No doubt, the conclusion to the Humanist Manifesto I clearly reflects the anti supernatural and optimistic, self-centered aims of its signers. They write:

Though we consider the religious forms and ideas of our fathers no longer adequate, the quest for the good life is still the central task for mankind. Man is at last becoming aware that he alone is responsible for the realization of the world of his dreams, that he has within himself the power for its achievement. He must set intelligence and will to the task (Kurtz, 1973: p. 10).

However, contrary to the prophesies and convictions of the drafters of Humanist Manifesto I, World War II and Adolph Hitler rudely contradicted the unmitigated optimism of the secular humanists. McDowell (1983) points out that, not only had World War I failed to rout evil, but evil had reared its ugly head much more powerfully through the Nazi atrocities of World War II. Having rejected the supernatural and a higher judge in favour of the basic goodness and perfectibility of man, the secular humanists turned toward modifying their previous statements. Kurtz and Wilson explained the need for a new manifesto. They write:

It is forty years since Humanist Manifesto I (1933) appeared. Events since then make that earlier statement seem far too optimistic. Nazism has shown the depths of brutality of which humanity is capable. Other totalitarian regimes have suppressed human rights without ending poverty. Science has sometimes brought evil as well as good. Recent decades have shown that inhuman wars can be made in the name of peace. The beginning of police states, even in democratic societies, widespread government espionage, and other abuses, of power by military, political and industrial elites, and the continuance of unyielding racism, all present a different and difficult social outlook. In various societies, the demand of women and minority groups for equal rights effectively challenges our generation (Kurtz, 1973: p. 13).

Based on the above mentioned unfavourable social outlook of our times, Kurtz and Wilson state the need and the necessity for affirmative and hopeful vision and faith commensurate with advancing knowledge. They further added that as in 1933 humanists still believe that traditional theism, especially faith in 
the prayer-hearing God, assumed to love and care for persons, to hear and understand their prayers, and to be able to do something about them, is an unproved and outmoded faith. For them Salvationism, based on mere affirmation still appears as harmful, diverting people with false hopes of heaven hereafter. They conclude that reasonable minds look to other means for survival and that today it is their (humanist) conviction that humanism offers that alternative that can serve present needs and guide humankind toward the future (Kurtz, 1973).

Being no longer content and certain to let basically good mankind evolve naturally toward his zenith, the secular humanists are now poised to help accomplish that transformation as quickly as they can by thwarting the evil of the few evil men. This objective is declared in the introduction to the resolutions in the second creed. It states:

Humanity, to survive, requires bold and daring measures. We need to extend the uses of scientific method, not renounce them to fuse reason with compassion in order to build constructive social and moral values. Confronted by many possible futures, we must decide which to pursue. The ultimate goal should be the fulfillment of the potential for growth in each human personality. Not for the favoured few, but for all mankind only a shared world and global measures will suffice. A humanist outlook will tap the creativity of each human being and provide the vision and courage for us to work together. This outlook emphasizes the role human beings can play in their own spheres of action. The decades ahead call for dedicated, clearminded men and women able to marshal the will, intelligence, and cooperative skills for shaping a desirable future. Humanism can provide the purpose and inspiration that so many seek; it can give personal meaning and significance to human life (Kurtz, 1973: pp. 14-15).

The excerpt above gives us an insight into the purpose of humanism. The preciousness and dignity of the individual person is a central humanist value. Individuals should be encouraged to realize their own creative talents and desires. Humanists reject all religious, ideological, or moral codes that denigrate the individual, suppress freedom, dull intellect, and dehumanize personality. They believe in maximum individual autonomy consonant with social responsibility. Although science can account for the causes of behaviour, humanist believe that possibilities of individual freedom of choice exist in human life and should be increased.

To be honest, this is a noble purpose, an ideal that must be pursued. However, the question is has humanism achieved this ideal? Can humanism achieve this? Are the realities of our world today in consonance with these ideals? Is our world today free from the social and environmental crises that negate these ideals? The answer is No. But why? Or is it because humanists are mistaken in these ideals? It is neither the case. The ideals are not in themselves impossibilities though they are not easy to realize given the nature of the human person. Humanists are not mistaken in pursuing these ideals. In fact, these are noble ideals and the dream of mankind. However, the failure humanism has recorded and continues to record and will continue to record lies in the philosophy behind humanism. That philosophy is in fact counterproductive to humanist pursuit of human dignity and worth. This is what we are out to argue in this paper.

\section{A Critical Look at Atheistic Humanism Vis-a-Vis Human Dignity}

We intend to show the counterproductive nature of humanism in its quest for human dignity through though a general critique of humanism. There are 17 propositions contained in Manifesto II and these propositions can be grouped into six namely: religion, philosophy, mankind, society, one-world government and science.

The first resolution under religion is that traditional dogmatic or authoritarian religions that place revelation, God, ritual, or creed above human needs and experience do a disservice to the human species. And that any account of nature should pass the tests of scientific evidence otherwise such account is absurd and meaningless. Humanists claim that the dogmas and myths of traditional religions are by this standard absurd and meaningless. They equally claim that belief in the existence of the supernatural is either meaningless or irrelevant to the question of the survival and fulfillment of the human race because there is no sufficient evidence for it. Humanists claim that we can discover no divine purpose or providence for the human species and that while there is much that we do not know, humans are responsible for what we are or will become. No deity will save us; we must save ourselves.

The second resolution is that the promises of immortal salvation or fear of eternal damnation are both illusory and harmful. They distract humans from present concerns, from self-actualization, and from rectifying social injustices.

The world view expressed by these two resolutions is that God does not exist and that it is nature rather than God that is responsible for human existence. However, this is opposed to sound reason. McDowell argues that, "For primordial, nonintelligent mass to produce human intelligence assumes, contrary to reason, that an effect is greater than its cause. To account for that human intelligence by a higher intelligence in whose image the human was made, and who sustains the very life of the human and his world, is reasonable, and biblical" (McDowell, 1983: p. 8). In fact, for humanists to blithely dismiss all religious philosophy and all evidence in support of God's existence in two simple propositions does not settle the matter of God's existence. We rather believe that our reasoning ability given to us by God in whose image we are created, and that responsible use of our reasoning ability to understand the world around us can lead us to sound evidence for the existence of God. Richard Purtill (1981: pp. 12-13) corroborated this idea when he writes that,

If we begin to ask fundamental questions about the universe, and follow the argument where it leads us, then it will lead us to belief in God; that if we examine the evidence of history and of human experience, we will be compelled to acknowledge that the only satisfactory explanation of the evidence leads us to Christianity. Such Christians acknowledge that there is still a gap between intellectual assent and commitment to a Christian way of life, but they believe that reason is neither opposed to such a commitment nor irrelevant to it-rather, it is the best possible ground for it.

Making his contribution to the issue of God's existence, the French philosopher Blaise Pascal states that, "The evidence of God's existence and his gift is more than compelling, but those who insist that they have no need of Him, will always find 
ways to discount the offer" (Pascal, 1985: p. 23).

In his attempt to re-establish the existence of God as against the claims of atheistic humanists that God does not exist, Dukor (2010: pp. 72-77) first lists about 14 arguments giving by the atheistic humanists to the conclusion that God does not exist. However, for the reasons of space, we only mention a few of them.

One, it is not possible to believe in all different gods which have been put forward from different religions. If they cannot all be true, then can none of them be true. Two, if God is omnipotent and all good, disasters cannot exist in the world. Three, if God is all good and he created all men and women in his own image, people cannot behave so abnormally. Four, to describe God as the originator of the universe is not an answer to the question where did everything start, for we need to know the origin of the originator. Five, God's purpose is not visible in the universe. Certainly there is no evidence that the universe's purpose leads up to mankind. Six, it is argued that God is derived from personal experience. It is a subjective experience, which is difficult to convey to those who have not experienced them. To the outsider, they might be regarded as hallucinations or imagination. Since, some people do not have such experiences they cannot be used to prove the existence of anything any more than someone might try to prove the existence of their dreams. Seven, theists have always claimed that it is up to the atheists to prove their atheism. On the contrary, it is up to theists to prove theism. In the same way in debating the existence of God, there should be a presumption of atheism, they argue.

Responding to these arguments, Dukor states that since atheism is the backbone or the foundation of humanism, or atheistic humanism to be precise, then there is the intellectual and practical need to dismantle the foundation by establishing strong arguments against the arguments of atheistic humanism. In doing this, Dukor states that God is the creator of man and humanism; that God is the first humanist not because he is a man but because he has, in grace, endowed man with the divine and providential gift of being elevated over and above all creatures of the earth and farther than that to conquer the rest of the creatures (Dukor, 2010). Dukor further opines that the atheistic humanists would have to believe that God is a humanist whether they believe in His sustenance or not and God again is the creator and founder of humanism contrary to the belief that man founded himself and founded humanism. Dukor makes this claim of the humanistic attributes of God on the basis of the submissions of the writer of Genesis chapter two:

Thus the heavens and the earth were finished, and all the host of them. And on the seventh day, God ended his work which he had made, and he rested on the seventh day from all this which he had made ... and every plant of the field before it was on the earth, and every herb of the field before it grew. For the Lord God had not caused it to rain upon the earth and there was not a man to till the ground. And the Lord God formed man of the dust of the ground, and breathed into his nostrils the breadth of life; and man became a living soul.

Based on the above scriptural excerpt, Dukor claims that all atheistic and philosophical arguments against God's existence are indirect arguments for the exaltation of God. He now takes up the above listed seven arguments and responds to them one after the other.

One, there are no gods of religions but God of religions which is the monotheistic God, the humanistic God and creator of man and humanism. The gods of religions which the atheistic humanists are using against the existence of God is the panpsychic and animistic gods of the ancient Africa, ancient Asia and ancient Europe, all of which have been conceptually and physically harmonized in the monotheistic God.

Two, in the face of disasters, the omnipotence and all goodness of God cannot be questioned. Disasters occur because man, like Voltaire, does not have the understanding first, that man has a freewill to have foreknowledge or not, to use it or not and the nots of all these could lead to disasters which in any case, according to Saint Augustine in his plenitude, is a blessing in disguise.

Three, people behave abnormally because they are atheistic and secondly because they lack the knowledge of the good or they refused to be good according to Socrates.

Four, from Genesis in the bible, we are told, and there is ample evidence to that effect, that God is the originator of the universe and the dust from which man is created and everything in the universe. He created matter from where the evolutionists traced everything. Logically the universe must have a beginning and the beginning is not the beginning of itself.

Five, God's purpose is visible in the universe. What the atheistic humanists think of man is what God created man for, that is, man's domination of all things in the earth and continuing the creative process started by Him.

Six, God and the whole universe is a subjective concept whose objectivity is in the objectivity of the earth and other galaxies. Perfection in the orderly arrangements in the universe is a matter of subjective but artistic appreciation. Therefore God as a perfect being can only be experienced subjectively and communicated intersubjectively.

Seven, it is up to atheists to prove that there is no God, no dreams, no intuition, no order in the universe, no perfection in creation, no spirit, no soul, no witchcraft, no devil, no creativity by man or God, no gods as evidence of God.

The only conclusion we can draw from Dukor's analysis here is that God is at the centre of man's life and the universe and therefore any life outside God or any attempt to understand the universe fully outside God will end up in meaninglessness and futility. And when life ends in futility and meaninglessness, it loses its dignity.

Be that as it may, the problem with humanism is not really whether God exists or not. The problem is the banishment of God, by humanist from human existence and experiences. The humanists claim that man has no need of God in his life, that God holds no relevance or importance to man and his existence. Following from this, they also claim that there is no design or purpose of providence for the human species. This view devaluates man to a level below that on which God places him as His highest creation. The humanists pretend to esteem the human being above all else. In reality, as Manifesto II shows, the humanists take away all worth from mankind. How? Unless our worth is rooted and grounded in something objective and outside ourselves, we are of value only to ourselves, and can never rise above the impermanence of our own short lives. God is outside our finite and transitory universe and His love for us gives us a value which transcends not only ourselves but our finite universe as well.

In the world besieged by war, violence, hunger, diseases and general social disorder such as ours, there is no gainsaying the fact that we need courage to keep life going. And that this 
courage is founded on hope and faith in a loving, caring and faithful God. This is the succor that religion or belief in God brings; and this is not an empty succor. Without such belief or faith, life becomes absurd and meaningless in the face of disappointments, failures and difficulties. This perhaps explains why there are many cases of suicide in many secular (humanist) societies like America than there are in religious societies like Africa. Despite the high level of sufferings in Africa most Africans do not take to suicide. They go through the sufferings and challenges of life with hope and faith that things will get better one day, and sooner or latter, things do get better. Miracle is a function of belief and faith in God's intervention in the affairs of man. Africans or those who believe in miracles do receive miracles from God for their challenges. There are verifiable cases of miracles amongst Africans and indeed amongst those (any where) who believe in God's existence and God's involvement in man's affairs. This is the pragmatic benefit for belief and faith in God.

To Africans and indeed to anyone who believes in God life is therefore not absurd and meaningless even in the midst of disappointment and difficulties. One thing that is anti-human progress and in fact, anti-human dignity is an attitude of faithlessness, lack of courage and the inability to hold on to life in the face of life challenges. There is nothing dignifying of man to lose courage, faith and hope for the future, and then ends one's life either through suicide or euthanasia, because of the present challenges of life. But the ability to hold on to the future, even when it is irrational to do so, is a function of faith in God who is involved in human affairs. This is one attitude that humanists lack and this perhaps explains why they may not see anything wrong with suicide or euthanasia. And this may also explain why there are many cases of suicide in secular (humanist) societies. Is there any dignity of life in such attitude? Does such attitude contribute positively to the quest for human dignity by humanism? Unfortunately, the answer is No.

Giving credence to the above submissions, Dukor is of the view that the whole of African philosophy and even that of Indian philosophy is replete with humanism that is theistically coloured. It is humanistic because it is centered on man's essence and existence but it is also theistic because it makes a strong reference and link to God who is at the centre of man's existence and experiences. Therefore the Indians and indeed the Africans manifest deep faith in God in dealing with their various existential experiences in life both positive and negative. They recognize the fact that God is the authority over the affairs of men. Dukor writes,

Buddha's historic science about God as the metaphysical entity and supernatural authority in the affairs of men is humanistically motivated. On the other hand, the African attitude is that theism or conception of God is a necessary denomination in all human affairs. In Indian philosophy and African philosophy we find that in a particular sense, these philosophies are humanistic but their humanism is combined with theism (Dukor, 2010: pp. 63-64).

What Dukor is saying here is that Indian and African philosophies of man is humanistic and at the same time theistic giving their deep rooted faith in the spiritual. He recognizes the fact that this recognition of and acceptance of the spiritual element in man has enabled them to deal with the problem of suffering and have converted same to an advantage unlike their counterparts in heavily atheistic humanistic environments who are easily defeated in the face of sufferings.

Having banished God from human existence humanists believe that man need nothing outside him, nothing transcendent, to save him; that man can save himself. This is what humanist Manifest II states. While we believe this statement was made somewhat tongue-in-cheek, since humanists do not believe man needs saving from anything, we do still need to comment on the statement. McDowell has argued that it is impossible for man to save himself in all circumstances. He writes,

While we would grant that man could "save himself" from falling after a slip by grabbing a railing, for example, it is not always possible. Picture a man in the middle of a large lake. He has fallen from his boat, which is now hopelessly out of reach. He has been in the frigid water for two hours. He can no longer keep himself afloat. His body temperature is fallen rapidly. He is being delirious. Would he find solace and genuine help in a bystander's admonition to "save himself"? Of course not. Without outside intervention, he will die. The spiritual (moral) condition of man is such that he is past the point of it saving himself. He needs outside intervention ... and that intervention is from God. (McDowell, 1981: p. 14).

By intervention here, McDowell means salvation from God. That man needs salvation is a truism. Most religions of the world attest to this truth. And this truth negates humanists' claim to man's self-sufficiency and basic goodness. Man is not self-sufficient. No one has more clearly expressed this point than the great Blaise Pascal, who was one of the seventeenthcentury pioneers of modern science, and incidentally invented one of the first arithmetical computing machines (It should be noted that modern science today i.e. scientism repudiates the idea of God and creationism). His famous pensees Thoughts on Religion and Philosophy (1894: pp. 9-10,46) contains some of the most penetrating analysis ever written of the predicament in which man lands himself by rejecting his creator's authority over his priorities. He says, "The essence of self-love is to love only oneself, to be interested for nothing but oneself. But what is gained by this? A man cannot prevent this object of his love from being full of defects and miseries, he wishes to be great, and sees himself to be little, he wishes to be happy, and feels himself miserable; he wishes to be perfect, and sees himself full of imperfections, he wishes to be an object of esteem and love of his fellow men, and sees that his faults deserve their aversion and contempt. This embarrassment produces the most unjust and animal passion imaginable; for he conceives a mortal hatred against that truth which forces him to behold and condemn his faults; he wishes it were annihilated, and unable to destroy it in its essence, endeavours to destroy it to his own apprehension, and that of others; that is he employs his utmost efforts to conceal his defects, both from himself and others, and cannot bear that men should point them out to him, or even see them. Certainly, to be full of defects is an evil, but it is a much greater evil, if we are full of them, to be unwilling to know the fact; since this is adding a voluntary illusion to their number ... what a chimera then is man! What a novelty! What a chaos! What a compound of inconsistencies! A judge of all things, yet a feeble earthworm: a depository of truth, yet a heap of uncertainty: the glory and the outcast of the universe”.

Pascal's message, however, is fundamentally not one of de- 
spair but of hope-the marvelous hope that comes when we stop pretending to self-sufficiency and accept the humbling Truth that can heal us. For amongst other astonishing facts of the Christian religion (and some religions) this is one, that it reconciles man to himself in reconciling him to God. Our self-will is never satisfied, even when it has obtained all it desires, but we are satisfied the instant we renounce it. Reinhold Niebuhr (1941: p. 213) has more pungently expressed this thought when he says, "Religion is not as is generally supposed an inherently virtuous quest for God, it is merely the final battleground between God and man's self-esteem.”

In the same vein, on his part, Mackay (1979: p. 113) states that, "man's truest dignity can be realized only by facing up to the reality, whatever the cost: whether it be at the cost of his self-esteem or anything else. If we pre-define what that reality must be, in a spirit of self-sufficiency and proud rejection of any claims on our obedience by our creator, we can block ourselves off from the one way in which we could discover what reality is about by coming to know its Giver-conversely, if we will only allow that Giver to get under our self-esteem, to re-order our priorities, we will find our eyes being opened. We will come to realize the truth-indeed the sobering truth-of the biblical diagnosis of our condition, and the glorious truth of the remedy that God has made available..." However, although man is lost and so needs salvation from God, it does not vitiate the greatness of man. Francis Shaeffer (1969: pp. 80-81) writes,

I am convinced that one of the great weaknesses in evangelical preaching in the last few years is that we have lost sight of the biblical fact that man is wonderful. We have seen the unbiblical humanism which surrounds us, and, to resist this in our emphasis on man's lostness, we have tended to reduce man to zero. Man is indeed lost, but that does not mean he is nothing. We must resist humanism, but to make man a zero is neither the right way nor the best way to resist it ... in short, therefore, man is not a cog in a machine; he is not a piece of theater; he really can influence history. From the biblical view point, man is lost, but great.

So said, the pronouncement of the death of God or the banishment of God from human existence goes without grave consequences for mankind. Mortimer writes that, "part of Nietzsche's brilliance was that he clearly saw and acknowledged the impact that the death of God would have on society. I believe that he predicted the twentieth century would be the bloodiest in history, as people grappled with his "truth" but that this negative impact would be temporary, ceasing with the emergence of the superman. I think that he was half-right-the twentieth century has indeed been bloody". Why does Mortimer consider Nietzsche's prophesy half right? It is because the twentieth century has indeed been bloody but to say that such negative impact would cease with the emergence of the superman would be untrue.

The bloody nature of our century today also invalidates secular humanist claim that man is naturally good. Secular humanism assumes that everyone is basically good and that evil comes from outside people and societies, rather than from within. However the realities of our times negate the truth of this claim. There are wars, and counter war terrorism and other violent crimes, from Africa to Europe; from America to Asia, all wasting lives and properties at colossal levels. Where lies the natural goodness of man? Even Thomas Hobbes' hypothetical state of nature where life is nasty, brutish, and short and man a wolf to his fellow man casts doubt to the claim of the natural goodness of man. For the evils of our society to cease, individuals need fundamental moral change. But this change cannot be possible with the denial of the existence of a grand moral norm or the moral law to which man's action must conform. This denial of any moral law is another problem with humanism with regards to its quest for human dignity.

The second major division in Manifesto II covers propositions three and four and relates mostly to philosophy. The third proposition affirms that moral values derive their source from human experience; that ethics is autonomous and situational, needing no theological or ideological sanction; that ethics stems from human needs and interest. This is a denial of any absolute moral standard, any grand norm or moral law which should define and regulate man's actions and behaviours. The summary of this is that morality is relative and subjective. However, this view is replete with contradictions and grave implications.

The humanists are right to point out that their ethics (morals) are situational. Since they are based in and come forth from the individual, they are necessarily self-centered and subjective. They have no objective basis or root. On the surface this appears to promote one's idea of the importance and power of man. However, upon closer examination, we find flaws with this view. If moral values are determined from human experience, there is no objective basis for calling anything right or wrong. There is no such thing as intrinsic good or intrinsic evil. Whether something is good or not depends on the context of the individual or the group of like-minded individuals in the society. On this basis could we condemn the society of Nazi Germany for judging the moral value of Jewish life as worthless? Would we have the right to call it bad? What if happiness in one society is eating one's enemy instead of convincing him to surrender?

Humanism does not offer any absolute value system; therefore mankind has no absolute system of right and wrong. In such an instance, why should I believe and accept the value system of the group (society) of men who drafted and signed Manifesto II? What compelling reason can they give me for accepting their dogmatic ethical assertion that "vulgarization, commercialization, bureaucratization, and dehumanization are debasing”. What if I happen to believe that it is good to promote vulgarization, commercialization, bureaucratization and dehumanization? In the same vein, in his critique of atheistic humanism, Dukor writes,

Humanists say that every responsible human being should be free to make his or her own choices and live their own life-style, as long as they do not violate the freedom of others. It would be impossible for humanists to force humanism on other people or to persuade non-humanists, for if they do, they will no longer be humanists (Dukor, 2010: p. 71).

McDowell rejects the relative morality of humanists based on its apparent contradiction and grave consequences. He writes:

The secular humanist position on relative moral values is almost the watershed for critiquing humanistic tenets. With no absolute ethic, why should we accept the humanists' moral value that the individual person is precious and deserves dignity in his own right? The Marxist, for exam- 
ple argues that the individual only has worth as a member of society. It is permissible indeed necessary, to expend the individual for the society. Why isn't the Marxist right? How can the humanist infringe on the Marxist's individual preciousness and dignity by telling him his view of mankind is wrong (McDowell, 1983: p. 18).

McDowell further states that Humanist Manifesto II has a contradictory statement about human sexuality; for while championing the autonomy of individual sexual rights, the statement also contradictorily makes bold universal moral assertions about some kinds of sex. He further asks "what right do the humanist signers of this manifesto have to say they do not approve of 'exploitive, denigrating forms of sexual expression' or 'mindless permissiveness or unbridled promiscuity'? What if an individual likes such sexual activity? If the humanists were to reply that such activity denies the rights of other parties, we must ask, what right have the humanists to say that those other rights should come before the particular individual's rights?” (McDowell, 1983).

So said, the humanists are against absolute moral values or universal moral standards. In fact, the beginning of Manifesto II declares that morals and values are relative and largely governed by society. Yet Humanist Manifesto II contains statements that contradict and betray their position on absolute moral values. Articles twelve, thirteen, fourteen and fifteen of Manifesto II express humanists' views on one-world government. Here are the articles and their theses:

Article Twelfth: "We deplore the division of human kind on nationalistic grounds. We have reached a turning point in human history where the best option is to transcend the limits of national sovereignty and to move toward the building of world community in which all sectors of the human family can participate. Thus we look to the development of a system of world law and a world order based upon transnational federal government..."

Article Thirteen: This world community must renounce the resort to violence and force as a method of solving international disputes. We believe in the peaceful adjudication of differences by international courts and by the development of the arts of negotiation and compromise...

Article Fourteen: The world community must engage in cooperative planning concerning the use of rapidly depleting resources. The planet earth must be considered a single ecosystem. Ecological damage, resource depletion, and excessive population growth must be checked by international concord. The cultivation and conservation of nature is a moral value...

Article Fifteen: The problems of economic growth and development can no longer be resolved by one nation alone; they are world-wide in scope. It is the moral obligation of the developed nations to provide-through an international authority that safeguards human right-massive, technical, agricultural, medical, and economic, including birth control techniques, to the developing portion of the globe.

In these four articles we find such absolute moral values as "the best option is to transcend the limits of national sovereignty", "belief in peaceful adjudication of differences by international courts and by the development of the arts of negotiation and compromise," "the cultivation and conservation of nature is a moral value" and "it is the moral obligation of the developed nations to provide ... massive ... assistance, ... to the developing portion of the globe”.
So then, it will not be out of place to state that men live by absolute ethics even if they claim to believe only in relative ethics. One may claim (as the humanists do) that all ethics and moral values are relative to one's society or to the individual conviction, but one rarely lives by such a maxim. This we have found to be true amongst humanists. So, try as we may, we cannot do away with the reality of absolute moral values or put in another way, morality as a "given". Why? Let us consider the origin of our moral sense. From whence come our moral sense? Francis Hutchenson, in the 18th century, proposed the moral sense theory but his critics ridiculed the theory by making it sound as if he has proposed an extra sense organ, such as a moral ear, or moral nose, which could "perceive" the moral qualities in actions and character traits. However, subsequent theories, it appears, were not able to do away with the idea of a capacity which appears to be universal among human beings, the capacity to approve and appreciate certain kinds of human conduct perceived as virtuous, and to disapprove of and discourage certain other kinds seen as vicious.

Concerning the origin of our moral sense, Franz Brentano in his work (1969) claims to discuss the Origin of our knowledge of Right and Wrong. However Brentano, rather than identify and establish the origin of our knowledge of right and wrong as he claims in his work, the book discusses the "origin of the concept of the good" which he ascribes to what he calls "intuitive presentations” (Brentano, 1969: p. 13). We however, wish to state that morality is a "given". By "giveness" we mean simply that the moral system, or morality, has the force and the universality of being "given", it is given to man qua man. Man did not invent it. Thus, there is no purely naturalistic, humanistic, positivistic or sociological theory that can explain morality without an inexplicable residue. Proponents of positivistic or sociological theory of morality are therefore merely speculating when they argue that there were "barbarians" who lived their lives as human being without any moral order (Etuk, 2010). It is of note that the same was said of Africans by Western scholars, i.e. that traditional Africans had neither sense of morality nor any sense of God etc. Today, it has been shown that it is not only fallacious, and spurious but also supercilious. Such theorists have not been able to identify when and where such barbarians lived, instead even in the best of the civilized and developed societies, some humans among them sometimes do things that would embarrass the worst "barbarians" such as poisoning hundreds of people in a communal mass suicide. Apparently not satisfied by such theories, Udo Etuk (2010: p. 5) asks, "Why should it be considered embarrassing for man to admit that there is a "giveness" about morality that is higher and more forceful than the society or the voice of parents? If it is the voice of parents or of the society that we have in every statement of "ought", then whence did the parents or the society derive it? Does it not appear that all of this is a vaguely veiled effort to evade the necessity of coming to terms with the question of the moral Lawgiver?”

God and not the individual or the society is the origin of our knowledge of right and wrong. To reject this, as the humanists have done, is to fall into the same error as the atheistic existentialist who first of all dismisses God and then complains that he is left in the world without a clue as to whence he came and whither he goes. In an effort to resolve this old question of how human beings come to have near-universal agreement in the characterization of some kinds of conduct or traits as "virtuous" and others as "vicious”, William Gass (1967: p. 526) says, "the 
moral hurdle has defied both the mathematical (i.e. intuitive/ deductive) method as well as the scientific or physical (i.e. the empirical/inductive) method. The difficulty for the mathematical method is the discovery of indubitable moral first premises which do not themselves rest on any inductive foundation and which are still applicable to the complicated issue of factors that make up moral behaviour". On the empirical approach to moral problems, Gass says,

It makes ethics a matter of expediency, taste, or conformity to the moral etiquette of the time. One is told what people do not what they ought to do; and those philosophers who still wish to know what people ought to do are told ... that they are asking a silly question (Gass, 1967: p. 527).

Etuk (1999: pp. 70-71) takes a strong stand against ethical naturalism (which is supported by secular humanism) and after attacking the theory that morality is nothing more than a social product concludes that:

Naturalism in ethics has had a long life, going back to the sophists in ancient Greece. But naturalism will always be at a loss to explain the binding force of the moral law; the insistence of the gnawing conscience; the universal human predicament which induces man whenever left to himself to go wrong; the intractable problem of sin which modern man has tried everything to escape from, but which contemporary psychiatrists are beginning to come to grips with; the joy and peace which come from the restoration of broken relationships; and many more things which go into the making of an ethical life. Naturalism will struggle but only in vain to get away from the fact that morality can only be fully anchored in the nature of the God who created man, and the entire universe, and therefore, has absolute right to decide how his world ought to be run.

So said, the essential giveness of the moral order presupposes that there is some kind of "Giver" contrary to the claim of the humanists. That it is given discards the possibility of man inventing it himself (therefore morality should not be relative to man); and that it is universal suggests also that the giver has to be a being who transcends cultures and societies. Perhaps it is the problem of having to come to terms with the being of this "Giver", with his characteristics which necessitated his establishing such an order in the first place, which has led scholars to invent all sorts of ways to circumvent him. But every attempt to circumvent this obviously central question of morality, whether it be the "intuitive presentations" of Brentano, or the ploy making every rational being "a law-making member of a kingdom of ends” (Kant), must falter.

The ethical views of secular humanists hold grave consequences for human dignity and society at large. If objective moral value is set aside and relative or subjective morality is enthroned, then everyman becomes a lawgiver and if everyman is a lawgiver, then everything is permitted. If everything is permitted, it is not unlikely that we would soon experience Thomas Hobbes' hypothetical state of nature where life is nasty, brutish and short, and every man a wolf to every other man. It is not difficult to see that such a society or situation cannot and will never guarantee the flowering of the dignity of man. Humanism has introduced to us a new world view, a new social and moral order. It is championing man's unrestricted freedom and liberty and everything is now permitted. The result is that abortion, premarital sex, homosexuality, lesbianism, rape, pornography, divorce and other forms of immoral and abnormal behaviours are on the increase in our societies today. It is not surprising because the essence of humanism is that man is the measure of all things. Man, not God, is the determiner of reality, meaning and ethics (Geisler, 1982). Take abortion for instance. The humanist may approve of abortion on many grounds. It may be on the ground of inconvenience to the mother (i.e. her dreams, ambitions, economic reasons or that she is free to determine what happens to her body) or the need to reduce population explosion. But we ask, does it contribute to the dignity and value of the individual human life to murder if it is inconvenient, if it doesn't fit into the world plan for conservation of resources or if it just happens not to have been born yet?

Another danger humanism poses to the quest for the dignity of the human person lies in its (humanism) evolutionary or naturalistic view of man. Having rejected God, humanism claims that man and indeed the entire universe is a product of chance. Mortimer Adler (1973) warns that if man continues to recognize no fundamental difference in kind between himself and the world of animals and machines, then his view of himself in terms of his moral dilemma or his metaphysical being must alter irretrievably. Anything left of contemporary concepts of morality and identity will be reduced to the level of the illusory, and the implications for individuals and for civilization are far-reaching.

According to the evolutionary, naturalistic world view, man is really no more than a sophisticated machine brought into existence by chance. Does man, according to this view, have value? No, not in the ordinary sense that people think of the value of human life. That is because a machine, no matter how sophisticated and unique, is still impersonal; it is still a machine. And even if one thinks of man as a great animal-the pinnacle of evolution-man is still just an animal. Very few secular humanists advocate radical vegetarianism. Very few secular humanists allow insects free reign on their homes and among their crops. Brian Schwerthly (2006: p. 11) writes that, "It is impossible to attribute a special, real, unique, lasting value to human life, if man is a chance-derived, impersonal machine destined to eternal extinction in the cosmic void. Human life value presupposes an immortal human soul and a personal beginning (i.e. creation by an infinite, personal God)". The secular humanist cannot justify attributing human life value to an impersonal, chance-derived machine. In the naturalistic system, not only is man just a sophisticated machine, he is also destined sooner or later to extinction when the universe inevitably expands into an icy death or contracts into a fiery ball. Secular humanists cannot avoid this eschatology of death, of ultimate extinction.

We make bold to state that in the areas of origins, being and eschatology (man's ultimate future), secular humanism really has nothing to offer except extinction into the cosmic void. The Humanist Manifesto II does make an attempt at future meaning for man when it speaks of man living on through children and culture. But this living on cannot last beyond a supernova; it cannot go beyond the death of the universe. But if in the end every one who ever lived ceases forever to exist, then life is meaningless, because if man's soul does not live on it will be as if no one ever existed. If morality is relative and if everything about life ends here, then it may not be difficult to understand 
why humanism leads to eugenics, abortion, euthanasia, labour camps and genocide and these are man's activities that are an affront to human dignity and the pursuit of human well-being.

\section{Conclusion}

There is no gainsaying the fact that respect to the dignity of man has become a necessity in our contemporary times given the various abuses to the human personality. We noted also that without respect to the dignity of man, the quest for human well-being will end up as a mere wish without any hope of realization. Atheistic humanists' attempt at restoring human dignity is therefore a bold step in the right direction. However, as we have noted, their attempt is a quest in futility given the logic of atheistic humanism. We choose to maintain with Dukor (2010: p. 79) the sentiment "that humanism without theism loses more than half of its values" and thus the capacity and the virtues necessary for pursuing human dignity; and that "No genuine humanism is possible which does not go beyond mere humanism, i.e., to be really human, man must have his beginning and end in God-humanity and deity are inseparably related" (Dukor, 2010: p. 79).

Since God is the source and ground for all human values and thus human dignity (Aquinas, 1892; Gyekye, 1996), any attempt to pursue the well-being of man in its totality outside God or without reference to God, who is at the centre of human affairs, will be doomed to failure. It is to be noted that in theistic humanism the spiritual element is the source of human values. Dukor (2010: p. 79) recognizes, with Rajkhanna and Sellers, the truth that human values are rooted in the spiritual and not essentially scientific. Any humanism therefore that must pursue human dignity must, as Dukor puts it, "be wedded to the cause of human values and must not admit anything that is destructive of human values". Atheistic humanism (which uses solely the scientific method) is concerned to explore the world of values and on that logic therefore cannot promote the cause of man who is a value-laden being. It is obvious that man is not fully satisfied with only the attainment of worldly aspirations and goals. He aspires for and becomes conscious of the beyond and in his quest for giving his aspirations and personality full expression he goes beyond the physical and the mechanical level and enters into a spiritual level.

\section{REFERENCES}

Abbagnano, N. (1967). Humanism. In Encyclopedia of Philosophy (Vol. 4). New York: Macmillan and Free Press.

Adler, M. (1973). The difference of man and the difference it makes. Downers Grove, IL: Intervarsity Press.

Angeles, P. (1981). Dictionary of philosophy. New York: Harper \& Row Publishers.

Aquinas, T. (1892). Summa theologica (Vol. 1). Rome: Leonine.

Brentano, F. (1969). The origin of our knowledge of right and wrong. London: Routledge and Kegan Paul.

Dukor, M. (2010). Theistic humanism of African philosophy. Germany: LAMBERT Academic Publishing.

Etuk, U. (1999). The new humanism. Uyo: Afahaide \& Bros.

Etuk, U. (2010). Moral personhood. In M. F. Asiegbu, \& J. C. Chukwuokolo (Eds.), Personhood and personal identity: A philosophical study (pp. 3-14). Enugu: Nigeria Philosophical Association.

Gass, W. (1967). The case of the obliging stranger. In M. Mandelbaum et al. (Eds.), Philosophic problems. New York: Macmillan.

Geisler, N. (1982). Is man the measure: An evaluation of contemporary humanism. Grand Rapids, MI: Baker Book House.

Gyekye, K. (1996). African cultural values: An introduction. Ghana: Sanfola publishing Co.

Kurtz, P. (1973). Humanist manifesto I and II. Buffalo: NY Prometheus Books.

Kurtz, P. (1973). The humanist alternative. London: Permberton Press.

Kurtz, P. (2000). Embracing the power of humanism. New York: Rowman \& Littlefield Publishers Inc.

MacKay, D. (1979). Human science and human dignity. London: Hodder and Stoughton.

McDowell, J. (1983). Handbook of today's religions: Secular humanism. New York: Amazon Publishers.

Niebuhr, R. (1941). The nature and destiny of man (Vol. 1). New York: Scribners.

Pascal, B. (1894). Thoughts on religion and philosophy. Edinburgh: John Grant.

Pascal, B. (1985) Pensees (No. 430). New York: Random House.

Schwertley, B. (2006). Results of secular humanism. London: Heinemann. 